\title{
EMIGRATION AND STABILITY IN HONG KONG
}

\author{
Wong Siu-lun \\ Department of Sociology \\ The University of Hong Hong
}

SOCIAL SCIENCES RESEARCH CENTRE OCCASIONAL PAPER 7

in association with the

DEPARTMENT OF SOCIOLOGY THE UNIVERSITY OF HONG KONG 
First published 1992

by the

Social Sciences Research Centre,

The University of Hong Kong,

in association with the

Department of Sociology,

The University of Hong Kong,

Pokfulam Road,

Hong Kong.

(c) 1991 Wong Siu-lun

Editorial subcommittee for the Department of Sociology:

Benjamin K P Leung, Carol A G Jones, Ng Chun Hung, Jon Vagg.

ISBN 962-7558-09-5 


\title{
EMIGRATION AND STABILITY IN HONG KONG
}

\author{
Wong Siu-lun \\ Professor of Sociology, \\ The University of Hong Kong
}

People in Hong Kong may not be keen to cast the ballot, but they are not shy to vote with their feet. ${ }^{1}$ They are emigrating in increasing numbers with the approach of 1997, the year in which Hong Kong will cease to be a British colony and become a special administrative region of China. According to official estimates, there were 22,400 persons leaving Hong Kong for residence overseas in 1980. This figure remained stable for several years. Then in 1987, three years after the signing of the Sino-British Agreement on the future of Hong Kong, the number of emigrants rose to 30,000. By 1990 the outflow of people reached a peak of 62,000 or about one per cent of the population, and it was expected to stay at that level in the near future. ${ }^{2}$

This outflow constitutes only the tip of the iceberg. There is a large pool of potential emigrants with the desire to leave. In the social indicators survey conducted in 1988 on a sample of 1,662 adults, 17.6 per cent of the respondents declared that they were planning to emigrate. ${ }^{3}$ A similar percentage was found in the survey commissioned by the City and New Territories Administration of the Hong Kong Government in 1990. In a sample of 1,661 persons, 16 per cent said they had plans to emigrate. ${ }^{4}$ In a series of telephone interviews carried out by Consumer Search Hong Kong Ltd. in 1990 on 500 respondents, those who said that they 'hoped' to emigrate comprised 30 per cent of the sample in February, 32 per cent in May, and 28 per cent in August. 5 Such survey findings clearly show that the size of the pool of potential emigrants varies according to how they are being defined, ranging from those who simply express a general wish to leave, to those who are actively finding ways to do so, and to those who have already submitted applications to become citizens in various countries abroad. The popular desire to emigrate also fluctuates widely, being affected by significant events such as the 1989 Tiananmen incident in China. 
The characteristics of the actual and potential emigrants are reasonably well known by now. They are predominantly 'yuppies' - young, educated, middle class professionals. According to official estimates for 1989, 48.8 per cent of the emigrants as compared with 32.3 per cent of the total population were between the age of 25 and 44 . About 14.5 per cent of the emigrants had a first degree or postgraduate qualification, and 23.3 per cent of them were employed as professionals, technical, administrative and managerial staff before they left. The corresponding percentages in the total population in 1986 were only 5.6 and 5.9 respectively. ${ }^{6}$ In the 1988 social indicators survey, it was found that '25.7 per cent of those below 30 years old, 36.8 per cent of those with high educational level, 44.2 per cent of those with a monthly income of more than ten thousand [Hong Kong] dollars, 36.9 per cent of the administrative and managerial workers, and 29.5 per cent of the professional and technical workers declared that they were planning to emigrate. ${ }^{7}$

This large scale emigration of the elites has caused alarm in Hong Kong. There are fears that such an outflow will undermine social stability for three main reasons. First, it is said that the brain drain will lead to a depletion of the 'functional core' of the economy. Second, it is felt that the widespread desire to leave will engender a doomsday syndrome and result in a state of anomie. Third, it is alleged that the desertion of the elites will create a crisis of legitimacy and an erosion of the moral basis of authority. Such worries are understandable, but they are not well founded. By scrutinizing each of them in turn, I shall argue that these concerns have been exaggerated. I hope to demonstrate that the present pattern of emigration is actually part and parcel of the prosperity and stability of Hong Kong. But before looking into the issues of brain drain, anomie and crisis of legitimacy, it would be instructive to review the nature and consequences of previous waves of emigration.

\section{Emigration in 1958 and 1967}

The history of Hong Kong as a British colony is a history of the movement of people in and out of the place. Emigration is not a new phenomenon. In the post-war period, at least two major waves of emigration have preceded the present one. The first wave occurred in 1958-61 as a result of the vegetable revolution in the New Territories, and the second wave was triggered by the 1967 riot which was a spill-over of the Cultural Revolution in China.

The first wave of emigrants in 1958-61 were mainly drawn from the rural areas of Hong Kong in response to an agricultural crisis. At that time, the traditional rice economy was giving way to vegetable cultivation introduced by new immigrants from the Chinese mainland who turned 
themselves into innovative farmers. For the rural inhabitants whose land were not suitable for the cultivation of cash crops, they had to look for alternate means of livelihood. A substantial number of them, such as the Mans of San Tin village, went abroad with the help of their lineages which provided loans and travel services to their members. ${ }^{8}$ As British subjects, these rural emigrants were admitted into Britain without any restrictions before the passage of the 1962 Commonwealth Immigrants Act. They set up Chinese restaurants in the United Kingdom and later diversified into other parts of Europe. So successful was the restaurant trade that remittances from these emigrants quickly transformed their home communities in the New Territories from precarious regions of production into prosperous areas of consumption. During that process, there was a simultaneous levelling of internal economic differences in the communities. The prolonged absence of adult men in those villages had created problems in security, marriage, sexual gratification, and the socialization of the young. Yet the overall effect was a strengthening of puritanical norms and community cohesion. 'Rather than acting as change agents,' James L. Watson writes, 'the retired emigrants are often among the most enthusiastic proponents of traditional values in San Tin'.9 The result of emigration was what he calls 'conservative change' in the New Territories.

While the first wave was basically an economic phenomenon, the second wave of emigration that came a decade later was triggered by a political crisis. The 1967 riot, led by local communists, began with demonstrations and work stoppages which turned into violent confrontation and terrorism. About 8,000 suspected bombs were reported; over 1,000 were found to be genuine. Fifteen persons were killed during the disturbance. ${ }^{10}$

The riot shook Hong Kong to its core. Many of its elites took flight. Unfortunately the social consequences of the riot have not yet been systematically studied, and there are only fragmentary information on the movement of people out of Hong Kong at that time. A survey of 253 senior local civil servants in 1972 found that nearly 60 per cent of them would like to emigrate if possible. 11 The United States was the most popular destination. In 1970, 9,720 immigrants from Hong Kong were admitted there. Restricted by quotas, the annual outflow to the US stayed around 10,000 persons in the 1970s and 1980s. The immigration record of Canada was more revealing. In 1970, 4,509 persons from Hong Kong landed in Canada. Then there was a sudden upsurge in 1973 to 14,662 persons which gradually subsided to 6,371 by 1977 . The steep rise in 1973 was evidently caused by a change in immigration policy in Canada. But it was also a dramatic indication of the pent-up urge to leave Hong Kong in the wake of the 1967 riot. ${ }^{12}$

How many of those who left during the second wave later returned to Hong Kong? No reliable figures are available, but it is reasonable to assume that the number of returnees is unlikely to have been large due to the high costs of relocation and the policies of host countries to encourage 
immigrants to settle permanently. In the 1988 social indicator survey, only 4.8 per cent of the respondents in Hong Kong said they had overseas residential rights and were probably returnees. ${ }^{13}$ Yet the loss of elites in the early 1970s did not result in social and economic chaos. Rather, Hong Kong experienced a period of sustained growth and stability afterwards. Since 1967 the gross domestic product has grown at an average rate of 10 per cent up to 1980.14 Instances of collective violence, reaching a peak of ten eruptions in 1965-69, tapered off with just four incidents in the 1970s. 15

Why was this so? Ian C. Jarvie, writing soon after the 1966 and 1967 riots, provided a clue. In his view, Hong Kong was riot prone because of the existence of an acute generation gap. A local identity was emerging among the young adults raised entirely in Hong Kong. 'Hong Kong is to them a home, not a haven of refuge, and they judge it by different standards than their refugee parents... They are experiencing a revolution of rising expectations'.16 But the 1967 riot, by highlighting the threat of communism and the precarious existence of Hong Kong, had actually served to dampen the rise of this indigenous identity and cool off the rising expectations among the young. Its unintended consequence was to reinvigorate the refugee mentality among Hong Kong Chinese families. The Shanghainese textile industrialists, for example, pursued more energetically their strategy of diversification of investments and spreading their children abroad. 17

This brief review should demonstrate that the two previous waves of emigration were both responses to threats of social disorder, not the causes of instability themselves. Now let us examine the three popular worries concerning the current exodus.

\section{Brain Drain}

Alarm over the loss of talents is a recurrent theme in the post-war development of Hong Kong. During the debate on the recent outflow, a group of scholars put forth the notion of the 'functional core' which they define as 'the subgroup of key personnel in an organization who are critical to its normal conduct of business'. They use a monthly income of HK\$12,500 and above as a reflection of functional importance, and estimate that there were 96,180 core personnel in the private sector and 33,983 in the civil service in 1989. If these people were gone, according to them, the economy would cease to function. ${ }^{18}$

The idea of the functional core is intuitively appealing, but it can easily create a confusion between roles and role occupants. Positions may be critical and indispensable, but not necessarily the individuals staffing them. Whether emigration will endanger the functional core 
depends very much on the rates of depletion and replenishment of the occupants of those key positions.

The rate of depletion in Hong Kong varies by occupational sector. According to Kwong and his associates, the rate could be as high as 35 per cent in 1987-88, prevailing among accountants and computer programmers. However, it could be as low as 6.5 per cent, as found among the general and production managers. 19 The organizational survey conducted by the Hong Kong Institute of Personnel Management on 318 companies showed an average staff turnover rate of 28.4 per cent in 1989. But emigration only accounted for a tiny 3.3 per cent of all resignations, even though the majority of those emigrating belonged to the managerial, supervisory, technical and administrative levels. ${ }^{20}$

The rate of depletion, though relatively high in some occupations, is not a haemorrhage. It is regulated by the immigration quotas and targets set by host countries such as the United States and Canada, and they are not amenable to quick changes. Therefore the outflow of talents is gradual and orderly under normal circumstances. However, an element of unpredictability is introduced by the British Nationality Scheme enacted in 1990. Under that scheme, 50,000 households in Hong Kong will be granted full British citizenship without residential requirements in the United Kingdom. The official intention is 'to give key people the confidence to remain in Hong Kong'21, but in effect it creates the possibility for large numbers of people to leave en masse at their own discretion.

Besides this element of unpredictability, the present outflow may lead to a loss of experience at the senior and middle levels in both private and public organizations. The quality of decisionmaking, particularly in crisis management, may decline. But such an impact, being intangible in nature, is difficult to gauge. It could well be neutralized by the benefits to be gained through an accelerated mobility and vigorous circulation of elites.

In order to replenish the depleting stock of talents, the Hong Kong government adopted a threeprong policy in 1990 to cope with the situation: 'in the short term by being more flexible over proposals for importing skills from neighbouring countries; in the medium term by facilitating the return to Hong Kong of former migrants, and in the long term by boosting output from Hong Kong's tertiary institutions'. ${ }^{22}$ But even without these new measures, there were more people coming into Hong Kong than going out throughout the 1980s. In 1990 there was a net gain of 11,581 persons according to official figures. ${ }^{23}$ Those who came in consisted of legal and illegal immigrants from China, and skilled and semi-skilled migrants from overseas. In Ronald Skeldon's assessment, such immigration and the 'natural production' by the local educational system would have more than compensated for the loss through out-migration, both in numbers 
and in quality. 24

However, there are two hidden dangers in the replenishment of manpower. The first is the sharp reduction in illegal immigrants from China after the 'reach-base' policy was abolished by the government in 1980. Previous to the change, illegal immigrants who had evaded capture at the border were allowed to stay. 'Net migration was about 400,000 during the 1950s, some 120,000 during the 1960s and another 500,000 during the 1970s. The inflow between 1978 and 1980 alone was nearly 400,000 comprising almost equal numbers of legal and illegal immigrants.'25 The illegal immigrants were predominantly young male adults who took up work as production workers, transport operators and labourers in Hong Kong. They supplied the bulk of the manpower in the manufacturing industry, and the enterprising ones among them later became small factory owners. Since the change in policy, illegal immigrants dwindled to 9,220 in 1980 and then rose again gradually to 27,826 in 1990, but it was still far below the level of influx in the 1970s. ${ }^{26}$ Concomitant with this decline, there developed in the Hong Kong economy an acute shortage of labour and a shrinkage in entrepreneurial supply. In surveys conducted in 1987, it was found that only 3.9 per cent of the small factory owners in Hong Kong were recent Chinese immigrants who arrived in the territory after 1978. But the corresponding proportion in Macau was nearly 29 per cent. The stream of illegal immigrants from China was apparently being redirected into Macau since 1978 because of the relative ease of entry, and the inflow spurred industrial growth there. ${ }^{27}$

The second danger is sharp fertility decline. The total fertility rate in Hong Kong fell rapidly since 1961 and reached replacement level in 1979. By 1986 the net reproduction rate had dropped to 0.64 , one of the lowest in the world. According to Ronald Freedman, 'if the fertility and mortality rates remained stationary at the 1986 level, eventually, as Hong Kong's population ages, population size would decline by 36 per cent per generation without taking migration into account'. ${ }^{28}$ However, the Hong Kong government shows no sign that it is taking the implications of this dramatic pattern of fertility decline seriously and is devising ways to deal with them.

Therefore, in my view, the popular alarm over the phenomenon of brain drain is misplaced. The real threat to the future socioeconomic well-being of Hong Kong is not the high rate of depletion of talents, but the hidden crisis of replenishment created by immigration and fertility reduction.

\section{Anomie and Moral Hazards}

Will Hong Kong degenerate into a state of anomie as 1997 approaches? Will the citizens there be infected by a doomsday syndrome and set in motion a self-fulfilling prophecy of social collapse? 
Popular apprehension is indeed pervasive. Collective pessimism about the future does exist. Most of the respondents in the 1988 social indicator survey had gloomy views about the social situation after 1997. The large majority of them anticipated a curtailment of civil rights (75.5 per cent), a reduction of individual liberty (73.2 per cent), a decline of the legal system (61.1 per cent), and a deterioration in living standards (66.9 per cent). In response to the question of whether life would be better and happier after 1997, more than half of them thought that to be unlikely. Nearly one in two of them said they were worried about political instability before 1997, and one in four of them believed that public order would deteriorate in the near future. ${ }^{29}$ That apprehension was shared by another group of respondents surveyed in 1990 by the Independent Commission Against Corruption of the Hong Kong Government. One in five of them thought that corruption cases would increase in the next few years mainly because of the mentality fostered by the problem of 1997.30 Furthermore, a disjunction clearly existed between the widespread desire to leave and the actual chances of emigration among inhabitants. It would be reasonable to assume that frustrated individuals might be tempted to take short-cuts in order to get rich quickly and to increase their chances of leaving. It should not be surprising to find local insurance companies reportedly concerned about the proliferation of fraudulent claims and the increase in 'moral hazards'.31

However, there is no evidence yet that anomie is becoming rampant. The overall reported crime rate in Hong Kong is very steady. There were 1,410 cases per 100,000 population in 1988 as compared to the rate of 1,223 cases in 1978. Only burglaries and serious narcotic offences had increased noticeably during the 10 year period. ${ }^{32}$ The suicide rate remained low. Only 616 deaths in 1989 and 587 in 1988 were determined by the coroners as being caused by suicide. ${ }^{33}$ Although the absolute number of divorce petitions had increased from 1,728 in 1978 to 5,893 in 1988, the divorce rate was still comparatively low: only 0.6 divorces per 1,000 inhabitants throughout the $1980 \mathrm{~s}$ in contrast to the 4.8 divorces per 1,000 in the United States. ${ }^{34}$

Rapid deterioration is unlikely to occur in the near future mainly because the process of emigration actually strengthens social control in two ways. Firstly, it acts as a safety valve to relieve frustration. Secondly, it reinforces social networks and checks massive deviance.

The attitudes of the Hong Kong people contain a curious paradox: collective pessimism about the post-1997 situation exists side by side with individual optimism about future advancement. As noted above, most respondents in the 1988 social indicator survey anticipated decline in important aspects of social life after 1997. Yet at the same time, they believed that the social standing of their children would be better than their own in the future. 'Nearly $80 \%$ of the respondents thought that their children would be in the middle (54\%) or the upper-middle (25\%) stratum. The optimism did not seem to wane too much even if the future means 1997 . The 
majority were of the view that the socio-economic status of their children would be better than their own both before and after 1997.'35

How can collective pessimism coexist with individual optimism? The paradox disappears if we distinguish between the attitudes of the elites from those of the masses. The elites have the option of leaving Hong Kong and they can pursue their dreams of advancement abroad. They probably see the prospects for their children in a cosmopolitan context. Those who have plans to emigrate, as shown in the 1988 survey, tend to be less satisfied with the existing situation in Hong Kong, more concerned with various social problems and less impressed with the government's ability in handling those problems. As a disgruntled and critical lot, they will disperse through emigration. Their discontent is unlikely to fester because of their transient status.

As for the masses in the lower social strata who have to stay, they see little prospect for themselves. But they have high hopes for their children. With the elites leaving town in large numbers, they perceive opportunities for mobility opening up for their children even though the overall socioeconomic condition in the future may not be as good as the present. That hope should reduce their frustration and sustain their commitment to existing social norms.

The elites and the masses do not share a common frame of reference. Their definitions of the social situation differ. Thus it is unlikely for them to act in concert to bring about a self-fulfilling prophecy of doom and disintegration. Furthermore, the process of emigration itself imposes control on individual deviance. Emigrants have to produce a certificate of no criminal record before they can gain entry into destination countries. However keen they may be in accumulating wealth, they must be careful not to run foul of the law and have their records tainted. They also have to rely on their social networks to help them to relocate. Assistance from friends and relatives are needed in securing information, advice and support in starting a new life in a foreign country. Potential emigrants need to uphold their personal reputation and nourish harmonious relationships within their social networks before they can tap the pools of good will. Since networks are overlapping in nature, very few individuals will have exactly the same circle of friends and relatives. Thus it is very difficult for a small band of people to collude in deviant acts and escape detection and social sanction.

The social order in Hong Kong is built on flexible and interwoven networks rather than on strong groups such as church communities, political parties or trade unions. By activating those networks, emigration serves to strengthen the foundation of such a social order, not weakening it. However, this type of social constitution has its own vulnerability. The chief one is that it is prone to the eruption of mass panic. The Hong Kong dollar crisis in September 1983 and the 
bank run after the closure of the Hong Kong branch of the Bank of Credit and Commerce in July 1991 are conspicuous examples. Rumours tend to spread rapidly through social networks during emergencies. The government is the only dominant institution with the ability to impose social discipline and command confidence in those circumstances. Therefore it has a special task, particularly in the current jittery times, to anticipate such eruptions and to prepare contingency plans well in advance on how to control the sudden outbursts of mass hysteria.

\section{Erosion of Authority}

During this transitional period, there is a growing concern about the crisis of legitimacy and the governability of Hong Kong. Ian Scott, for example, argues that the government has lost the support of critical social groups as shown in their mass desertion. 'Emigration may be interpreted as a vote of no confidence in the Special Administration Region government but it may also be inferred that many emigrants have no faith in the present government's ability to handle their future affairs. The rising tide of emigration ... alienated the young and better educated and eroded the moral basis of authority.'36

But Hong Kong is after all a colony. It is doubtful whether the government has ever had a moral basis of authority for it to command allegiance from the Chinese population in the first place. It would indeed be surprising, as Scott seems to prescribe, to find positive political support such as 'mass demonstrations backing the Hong Kong government'. ${ }^{37}$ Lau Siu-kai is probably closer to the mark when he describes the Hong Kong political arrangement as a 'minimally-integrated social-political system' with the bureaucratic polity and the Chinese society keeping each other at arm's length. 38 With such an arrangement, Hong Kong had enjoyed a long period of stability. A delicate balance was struck between a limited polity and a dynamic society. The former fostered 'system trust' by providing an administrative and legal framework which was conducive to fair competition. The latter thrived on personal trust and was propelled by a pervasive refugee mentality and entrepreneurial familism. ${ }^{39}$ In this set-up, the government was playing the role of a referee. It gained popular support through its efficiency and impartiality in enforcing the rules of the game. But it did not have the moral authority to lead and to mobilize the populace. Therefore increased emigration would not undermine its basis of legitimacy which was essentially pragmatic in nature. Rather, emigration might fortify the refugee mentality and entrepreneurial familism within the community and reinforce its dynamism.

The prevalent refugee mentality in Hong Kong has several key features. First of all, the actual or potential emigrants are mainly elites. They are pushed to leave by the perception of political threats. They are not pulled away by economic opportunities. They are 'yuppie' refugees, not sojourners. The second characteristic is a preference for 'exit' over 'voice' as the means to express 
dissatisfaction. 40 The majority of the Hong Kong people have a strong sense of political powerlessness. Recent political reforms notwithstanding, they continue to feel that they have very little influence on government policies. The third feature is an instrumental attitude towards the issue of nationality. Passports are regarded mainly as travel and insurance documents; they are not endowed with much emotional significance such as national commitment and loyalty. Moral judgments are suspended on other people's decision to leave or to stay. Fourthly, there exists a deep ambivalence towards China and a conflicting sense of identity. Most Hong Kong residents are torn between a revulsion against China as a communist state and an attachment to China as their motherland. Among the young and the educated, more of them begin to regard themselves primarily as 'Hong Kong people' rather than as 'Chinese'. There has developed a growing identification with Hong Kong, probably more as a way of life than as a place of residence. That identity can be mobile and cosmopolitan. The last feature is an emphasis on selfhelp and autonomy. Personal liberty is highly valued; poverty is seen as the result of individual inadequacies.

As a prevailing ethos, this refugee mentality does not exclude the co-existence of other orientations. On the other hand, neither is it confined to those with an expressed desire to leave. It appears to infect all those with family members or relatives abroad. Such a mentality induces immunity to political passions and ideological fervour within Hong Kong. It lowers popular expectations and demands on the polity. It tends to reduce the problem of legitimacy crisis into an academic issue.

But more important than its political impact, the refugee mentality actually creates a spirit of enterprise and engenders economic dynamism. ${ }^{41}$ It boosts the achievement motivation, encouraging most Hong Kong people to believe that one can become somebody through one's own effort. It reinforces the quest for educational qualifications as a form of mobile asset. It fosters a high rate of savings to prepare for the rainy day. It strengthens the habit of alertness and vigilance as shown in the local appetite for newspapers, mobile phones and fax machines.

The economic dynamism generated by the refugee mentality is complemented by a form of 'entrepreneurial familism'. 42 The basic unit of decision-making and risk-bearing in Hong Kong is the family. Throughout the social spectrum, it is within the family that resources are pooled and strategies devised to seek security and advancement. Individuals strive and compete within the webs of personal ties spun by the multitude of families, and they are seldom atomistic. Responding to the uncertain future, various families decide to diversify their physical and human capital and extend their networks globally. Through emigration, this entrepreneurial form of familism is enhanced rather than decimated. 
As noted earlier, Hong Kong is experiencing a rapid fertility decline. The ideal family size is decreasing and is matching the actual size. The norm as found in a 1987 survey was just two children with a notable minority preferring only one child or none at all. 43 Would this undermine the vitality of entrepreneurial familism? The reasons given by the respondents for not wanting more children did not indicate a weakening of the family. Nearly half of those interviewed justified their choice of family size with the statement that 'I hope to give every child as much education as possible'. Another 37 per cent of them said they did not want to have more children because of the financial burden involved. Other reasons, including the uncertain political prospect of Hong Kong, were regarded as insignificant. ${ }^{44}$ It was thus the concern for enhancing human capital and competitiveness - the core value of entrepreneurial familism - that led to decisions to have fewer children.

The popular course adopted by Hong Kong families is to invest in their children's education. In the next few years, the opportunities to acquire local tertiary qualifications will be rapidly expanded. The Hong Kong government announced in 1989 an accelerated plan to increase the number of first year, first degree places from about 7,000 at that time to 15,000 in 1995. This meant making tertiary places available to 18 per cent of the relevant age group in 1995 as compared to the 7 per cent in 1989. The dramatic move was made after the shock of the Tiananmen incident in China. The main aims, according to the government, were to cope with the exodus of talents, to upgrade skills for the future, and to satisfy parental demands so as to restore public confidence in the territory. 45 But it is very likely that this policy will lead to educational inflation and the depreciation of credentials. The high expectations of families will turn into discontent when their investments in education do not bring the anticipated economic rewards. Anomie, as Emile Durkheim has pointed out, feeds on insatiable desires. By prescribing the popular but wrong medicine of tertiary educational expansion for the symptoms of emigration, the Hong Kong government may in effect be sowing the seeds of anomie in the future by failing to keep the insatiable desires for qualifications in rein.

\section{Conclusion}

In a recent letter published in the Economist, a Mr. Muzaffar Ahmed takes Mr. Lee Kuan Yew, former Prime Minister of Singapore, to task for the latter's views on democracy and economic growth. 'Can Mr. Lee explain why,' Ahmed writes, 'in spite of spectacular growth, thousands of Singaporeans flee Singapore for a better life overseas? Why is it, in spite of rapid economic growth rates, people from Hong Kong, Taiwan and South Korea are interested in migrating to the United States, Australia and New Zealand?'46 
His letter reflects the popular use of the problem of emigration as rhetoric. In Hong Kong, it has been invoked by the government as a bargaining chip in political negotiations with China. It has been employed by various occupational groups to press for a bigger quota for their members in the British nationality package. Such rhetoric is conducive to exaggerations and tend to cloud our judgment. With careful analysis, it should be clear that the recent outflow does create difficulties of adjustment in the economy, but it does not constitute a crisis of stability. By overreacting to the rhetoric, the Hong Kong government may be adopting rash decisions that will only worsen the situation. The real issues, as accentuated by the recent wave of emigration, are problems of restrictive immigration and fertility decline which endanger the replenishment of talents. As real threats to the socioeconomic future of Hong Kong, it is these two issues that call for urgent attention.

But the letter also serves to put the case of Hong Kong into comparative perspective. The size of its recent wave of emigration is indeed eye-catching, but Hong Kong is by no means unique in the massive outflow of population. In this respect, the 'four little dragons' are in good company. For instance, in 1989, the United States admitted more immigrants from Korea $(31,604)$ and Taiwan $(14,705)$ than from Hong Kong $(12,236)$. As for sending immigrants into Australia, Hong Kong topped the list with 9,998 persons (about 1.78 per thousand population) in 1988/89, but Singapore was not far behind with 2,806 persons (1.06 per thousand population). ${ }^{47}$ Moreover, the emigrants from these areas seem to have a similar profile. They tend to be young, educated professionals. 48

Thus the 'four little dragons' have more things in common than their similar rates of economic growth. All of them are stressing competition through education, experiencing rapid fertility decline, and exporting people as well as goods. One wonders whether the refugee mentality is one of the common denominators among them. Hong Kong may be special in having a definite date with destiny in 1997, but it shares with the other three 'dragons' a similar history of refugee influx, an uncertain political future, and a collective sense of anxiety and nervousness that impels economic endeavour. Massive migration and spectacular economic growth may well be two sides of the same coin. Outflow of people and internal social stability may well go hand in hand in these edgy communities. 


\section{Notes}

1. An earlier draft of this paper has been presented in seminars at the Centre of Asian Studies, University of Hong Kong on 11 April 1991 and at the Department of Sociology, National University of Singapore on 15 August 1991. This paper is an outgrowth of the research project on 'Emigration from Hong Kong: Tendencies and Impacts' which is being funded by the University and Polytechnic Grants Committee in Hong Kong. Other researchers in the project include Professor Y. K. Fan, Dr. Daniel Cheung, Dr. K. C. Lam, Dr. Elizabeth Sinn and Dr. Ronald Skeldon who have given me much intellectual stimulation and support. I am also grateful to Professor R. D. Cremer and Dr. Jon Vagg for their useful comments on the draft.

2. These official estimates, made by the Government Secretariat in Hong Kong, are cited in R. Skeldon, 'Emigration and The Future of Hong Kong', Pacific Affairs, Vol. 63 (1990), p. 502, Table 1.

3. S. K. Lau, H. C. Kuan, and P. S. Wan, 'Political Attitudes', in S. K. Lau, M. K. Lee, P. S. Wan and S. L. Wong (eds.), Indicators of Social Development: Hong Kong 1988 (Hong Kong: Hong Kong Institute of Asia-Pacific Studies, The Chinese University of Hong Kong, 1991), p. 179.

4. South China Morning Post, 22 May 1990.

5. Hong Kong Economic Times, 5 March 1990 and 28 August 1990; South China Morning Post, 29 May 1990.

6. Estimates of the Government Secretariat in Hong Kong, cited in Skeldon, 'Emigration and the Future of Hong Kong', p. 508.

7. Lau, Kuan and Wan, 'Political Attitudes', p. 179.

8. A lineage is a kinship group consisting of all descendants in one line of a particular person through a determinate number of generations. For the lineages in Hong Kong, see James L. Watson, Emigration and the Chinese Lineage: The Mans in Hong Kong and London (Berkeley: University of California Press, 1975), and Maurice Freedman, 'Emigration from the New Territories', in G. W. Skinner (ed.), The Study of Chinese Society: Essays by Maurice Freedman (Stanford: Stanford University Press, 1979), pp. 223-31.

9. James L. Watson, Emigration and The Chinese Lineage, p. 215.

10. Ian Scott, Political Change and the Crisis of Legitimacy in Hong Kong (Hong Kong: Oxford University Press, 1989), pp. 98-9.

11. Aline K. Wong, 'The Study of Higher Non-Expatriate Civil Servants in Hong Kong' (Chinese University of Hong Kong, Social Research Centre, occasional paper, 1972), p. 43.

12. For the immigration figures into the United States and Canada, see Skeldon, 'Emigration and the Future of Hong Kong', p. 504, Table 2. 
13. Lau, Kuan and Wan, 'Political Attitudes', p. 179.

14. See A. J. Youngson, Hong Kong Economic Growth and Policy (Hong Kong: Oxford University Press, 1982), pp. 8-9.

15. Benjamin K. P. Leung, 'Collective Violence: A Social-structural Analysis', in B. K. P. Leung (ed.), Social Issues in Hong Kong (Hong Kong: Oxford University Press, 1990), p. 148.

16. I. C. Jarvie, 'A Postcript on Riots and The Future of Hong Kong', in I. C. Jarvie and J. Agassi (eds.), Hong Kong: A Society in Transition (London: Routledge \& Kegan Paul, 1969), p. 363.

17. Wong Siu-lun, Emigrant Entrepreneurs: Shanghai Industrialists in Hong Kong (Hong Kong: Oxford University Press, 1988), pp. 37-41.

18. Paul Kwong, Pak-wai Liu and Stephen Tang, 'Functional Core of The Labour Force: Towards The Retention of Key Personnel in Hong Kong', Department of Sociology and Department of Economics, The Chinese University of Hong Kong, mimeo., December 1989, p. 30. See also Paul C. K. Kwong, 'Emigration and Manpower Shortage', in Richard Y.C. Wong and Joseph Y. S. Cheng (eds), The Other Hong Kong Report 1990 (Hong Kong: The Chinese University Press, 1990), pp. 297-337.

19. Kwong, 'Emigration and Manpower Shortage', p. 307.

20. Sara F. Y. Tang, Emigration from Hong Kong: 1990 Organizational Survey (Hong Kong: Hong Kong Institute of Personnel Management, 1990), p. 2, 62-3, and 69. It should be noted that the survey was conducted by mailed questionnaire and the response rate was only 14 per cent. It was designed with a bias towards large firms, even though small firms employing less than 50 workers made up nearly 92 per cent of the manufacturing establishments in Hong Kong. Its original sample covered all of the firms employing over 200 workers, 27 per cent of the those employing 100-199 workers, and just 10 per cent of the those employing 20-99 workers.

21. D. Roberts (ed.), Hong Kong 1991: A Review of 1990 (Hong Kong: Government Printer, 1991), p. 375.

22. D. Roberts (ed.), Hong Kong 1991, p. 375.

23. R. Skeldon, 'Emigration, Immigration and Fertility Decline: Demographic Integration or Disintegration?', in Sung Yun-wing and Lee Ming-kwan (eds.), The Other Hong Kong Report 1991 (Hong Kong: Chinese University Press, 1991), p. 248.

24. ibid., p. 250.

25. Census and Statistics Department, Hong Kong, Hong Kong 1981 Census Main Report Volume 1: Analysis (Hong Kong: Government Printers, 1982), p. 75.

26. The figures are based on the unpublished tabulations provided by the Immigration Department of the Hong Kong Government and cited in R. Skeldon, 'Emigration, Immigration and Fertility Decline', p. 245. 
27. Wong Siu-lun, 'Chinese Entrepreneurship in Macau', in R.D. Cremer (ed.), Industrial Economy of Macau in the 1990s (Hong Kong: API Press Ltd., 1990), p. 30. See also V. F. S. Sit, R. D. Cremer and S. L. Wong, Entrepreneurs and Enterprises in Macau (Hong Kong: Hong Kong University Press, 1991), p. 58.

28. The Task Force on the Study of Family Planning Knowledge, Attitude and Practice in Hong Kong 1987, Report on the Survey of Family Planning Knowledge, Attitude and Practice in Hong Kong 1987 (Hong Kong: The Family Planning Association of Hong Kong, 1989), p. 5.

29. Wong Siu-lun, 'Prosperity and Anxiety in Hong Kong Reexamined', paper presented at the conference on social indicator studies in Chinese societies, Chinese University of Hong Kong, 6-7 December 1990, pp. 5 and 22. This paper is forthcoming in the conference proceeding to be published by the Institute of Asian and Pacific Studies of the Chinese University of Hong Kong. See also Lau, Kuan and Wan, 'Political Attitudes', p. 176.

30. $\quad$ Ming Pao, 26 October 1990, p. 5.

31. South China Morning Post, 6 August 1990.

32. Census and Statistics Department, Hong Kong, Hong Kong Social and Economic Trends 1978-1988 (Hong Kong: Government Printer, 1989), pp.72-3. See also M. Smith-Morris (ed.), The Economist Book of Vital World Statistics (London: Hutchinson Business Books Ltd., 1990), p. 246.

33. South China Morning Post, 17 August 1990.

34. Hong Kong Digest of Social Statistics (Hong Kong: The Council of Social Service, Research Department, 1990), p. 22; Smith-Morris, Economist Book of Vital World Statistics, pp. 224-5.

35. Thomas W. P. Wong, 'Inequality, Stratification and Mobility', in Lau et al., Indicators of Social Development, p.168.

36. I. Scott, Political Change and The Crisis of Legitimacy in Hong Kong (Hong Kong: Oxford University Press, 1989), p. 328.

37. ibid., p. 328.

38. Lau Siu-kai, Society and Politics in Hong Kong (Hong Kong: The Chinese University Press, 1982).

39. For elaborations on the ideas of system trust, personal trust, refugee mentality and entrepreneurial familism, see Wong Siu-lun, 'Chinese Entrepreneurs and Business Trust', University of Hong Kong: Supplement to The Gazette, Vol. 37, No. 1, 1990, pp. 25-34; Wong Siu-lun, 'Prosperity and Anxiety in Hong Kong Reexamined', in S. K. Lau, M. K. Lee, P. S. Wan and S. L. Wong (eds.), The Development of Social Indicators Research in Chinese Societies (Hong Kong: Institute of Asia and Pacific Studies, The Chinese University of Hong Kong, forthcoming); and Wong Siu-lun, 'The Applicability of Asian 
Family Values to Other Sociocultural Settings', in P. Berger and M. Hsiao (eds), In Search of An East Asian Development Model (New Brunswick: Transaction Books, 1988), pp. 134-52.

40. On the distinction between exit and voice, see A. O. Hirschman, Exit, Voice, and Loyalty: Responses to Decline in Firms, Organizations, and States (Cambridge: Harvard University Press, 1970). For survey findings about political powerlessness, see Lau Siukai and Kuan Hsin-chi, The Ethos of the Hong Kong Chinese (Hong Kong: The Chinese University Press, 1988), pp. 94-5; Lau, Kuan and Wan, 'Political Attitudes', p. 196-8.

41. For an extended analysis on this issue, see Wong Siu-lun, 'Prosperity and Anxiety in Hong Kong Reexamined'.

42. See Wong Siu-lun, 'The Applicability of Asian Family Values to Other Sociocultural Settings'.

43. In the survey, it was found that $4.8 \%$ of the respondents did not want to have any children, $10.1 \%$ wanted only one child, $58.4 \%$ wanted two and $16.1 \%$ wanted three. See Task Force, Report on The Survey of Family Planning Knowledge, Attitude and Practice in Hong Kong 1987, p. 40.

44. ibid., pp. 39-41.

45. See David Wilson, 'A Vision of The Future', in D. Roberts (ed.), Hong Kong 1990 (Hong Kong: Government Printer, 1990), pp.12-13.

46. Economist, 3 August 1991, p. 4.

47. For immigration figures pertaining to the United States and Australia, see Skeldon, 'Emigration and The Future of Hong Kong', pp. 519-20.

48. See for example Yap Mui Teng, 'Singaporeans Overseas: A Study of Emigrants in Australia and Canada' (Singapore: The Institute of Policy Studies, Report No. 3, 1991), pp.11-14. 
【香港的移民現象和社曾安定】

黄紹侖

自促中英政府在八十年代初期對香港前途展開談判之後，香港市 民移居外國的数字便大幅度上升。到了一九九 0 年，移民人數踓升至六

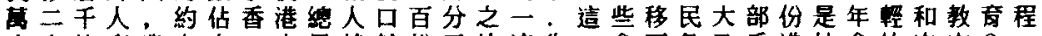
度高的專羓人士。大量精英份子的流失，會否危及香港社會的安定？

本文首先回頙在一九五八年和一九六七年的兩次移民潮，指出人

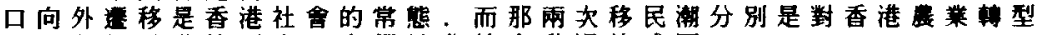

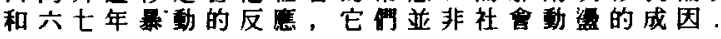

然後本文對有网近期移民的三種論點加以分析 . 其一是人才流失

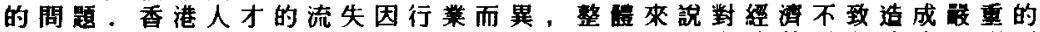

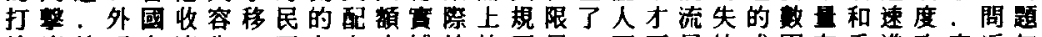
的結不在流失，而在人才補給的不足。而不足的成因在香港政府折年

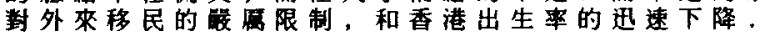

其二是移民現象可能造成的末世心热和社會解觛的危機。但社合

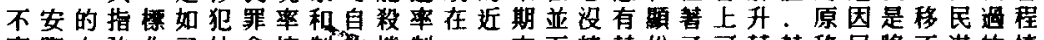

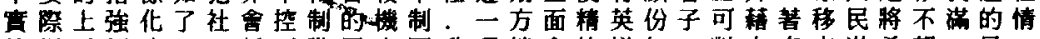

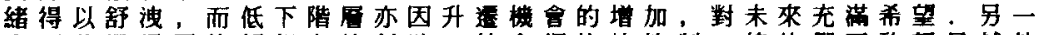

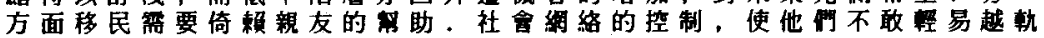

其三是精英份子的外移可能削臂香港政府的威信，但是香港政府 的统治，是建基於它的效率和克制，及對大部份的茟人社合保持道當的

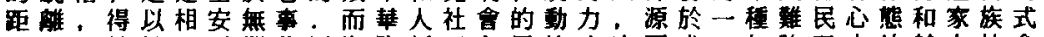
的企業精神。近期移民潮降低了市民的政治要求。加強了本地華人社會 的動力。所以不會對香港政府的统治椣成負面的威育.

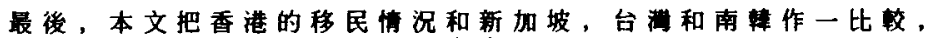
指出『四小龍』在䔔方面有根多相似之战。 